\title{
単一液滴の乾燥過程と噴霧熱分解法による酸化物微粒子の 生成機構の解析
}

\author{
劉 天泉・桜井修・加藤誠軌・水谷惟恭 \\ (東京工業大学工学部無機材料工学科, 152 東京都目黒区大岡山 2-12-1)
}

\section{Analysis of Drying Process of a Single Droplet and the Formation Mechanism of Oxide Fine Particles by Spray Pyrolysis}

\author{
Tian-quan LIU, Osamu SAKURAI, Masanori KATO and Nobuyasu MIZUTANI \\ $\left(\begin{array}{l}\text { Department of Inorganic Materials, Faculty of Engineering, Tokyo Institute of Technology, } \\ 2-12-1 \text {, Ookayama, Meguro-ku, Tokyo } 152\end{array}\right)$
}

\begin{abstract}
The formation mechanism of solid particles derived from droplets by spray pyrolysis was studied. A droplet of zinc nitrate aqueous or methanol solution weighing 1 to $3 \mathrm{mg}$ was set on the tip of a $0.1 \mathrm{~mm} \phi$ Pt wire. This droplet was dried in a furnace at a desired temperature. Decreases in weight and diameter of the droplet by evaporation of solvent were measured with a balance and a camera system. The (droplet weight) $)^{2 / 3}$ vs. time curve was divided into two parts: a straight portion in the first stage (part 1) and a curved one in the following stage (part 2). The critical particle size, which corresponds to the formation of hard shell on the surface of the droplet, was estimated from the droplet weight at the joint of part 1 and part 2. This critical particle size was sensitive to the drying temperature and increased when the drying temperature increased. This relationship was also confirmed in a spray pyrolysis process. For constant drying temperature, the porosity of the particles was constant even the initial concentration of droplets changed, and the particle size changed with 1/3 power of the initial concentration.

[Received July 14, 1989; Accepted October 3, 1989]
\end{abstract}

Key-words : Single droplet, Spray pyrolysis, Oxide fine particles, Drying process

\section{1. 緒 言}

噴霧熱分解法による粉末の合成法は，無機又は有機物 原料を水や有機溶媒に溶かした溶液を噴霧して微小な液 滴とし，これを加熱して溶媒を除去したのち，溶質を熱 分解して目的の酸化物微粒子を得る方法である.

噴霧熱分解法を用いて酸化物微粒子を合成した研究は 多いが，生成機構に関する研究はほとんどない，合成に 関する研究の多くも原料の種類, 濃度, 液滴径, 加熱速 度などの合成パラメーターと生成粒子との関係を調べた ものである。例えば，加藤ら ${ }^{1), 2)}$ はデル夕式噴霧器之二 重管式噴霧器を用いて, Zn-フェライトや酸化鉄を合成 し，溶質濃度が粒径に大きく影響することを指摘した。 また，溶液から固相が直接析出する場合には，加熱速度 が小さい場合のみ粒子は球状であるが, 一度融液を経て 酸化物に分解する場合には，加熱速度を大きくしても球 状を保ちやすいなどの結果を得た，神崎ら ${ }^{3)}$ は合成した スピネル微粒子（数 $\mu \mathrm{m}$ から十数 $\mu \mathrm{m}$ オーダー）に樹脂 を含浸させた後に研磨して粒子の内部を観察し, 溶媒中 の水とエタノールの割合と内部構造の関係を調べた。ま
た, Gardner ら ${ }^{4)}$ は原料塩の熱分解特性と合成した粒子 の形状との関連を調べた．更に，著者ら ${ }^{5), 6)}$ は金属アル コキシドのアルコール溶液を使って, 種々の温度で酸化 物微粒子を合成し, 原料調製法と合成温度が微粒子の内 部構造や組成分布に及ぼす影響について検討した。

一方, 化学工学の分野では固体の乾燥や液滴の蒸発之 乾燥等に関して多くの研究や理論解析 ${ }^{7,8)}$ が行われてい る. Charlesworth と Marshall ${ }^{9)}$ は溶質を含む単一液滴 を用いて蒸発による乾燥時間を測定した。彼らは蒸発速 度式から固相が析出して液滴の表面を完全に覆うまでの 時間を見積もり，その值は溶媒の沸点以下の温度で乾燥 を行った場合には実験結果とよく一致した。しかし，沸 点より高い温度の場合には実験の誤差が大きく, 液滴の 乾燥時間を正確に見積もることができなかったと報告し ている.

本研究では, ファインセラミックス原料粉の合成プロ セスに化学工学的な研究手法を応用してモデル実験を行 い, 単一液滴内での溶媒の蒸発や溶質の拡散之析出につ いて熱天秤やカメラ撮影の手法を用いて研究し, 噴霧熱 
分解法における乾燥段階の生成機構の解明を試みた. 更 に，超音波噴霧熱分解法による均一な粒径を持つ酸化物 球状粒子の合成における乾燥温度や噴霧原料溶液の濃度 と生成固体粒子との関係をモデル実験と対比させて考察 した。

\section{2. 実験方法}

\section{1 単一液滴の乾燥曲線の測定}

図 1 に単一液滴の乾燥過程を測定する装置の模式図を 示す．天科につり下げた白金線の先端に液滴を保持し， 加熱して液滴を蒸発させ，蒸発過程の重量変化を天科に よって測定した。また液滴の大きさの変化をカメラに よって測定した．保持した白金線の影響をできるだけ小 さくするため，0.1 mm $\phi$ の細い白金線を用いた。更に， より大きな液滴を保持させるために，白金線の先端を バーナ一で溶かして, 約 $0.4 \mathrm{~mm} \phi$ のさい白金球を 作った. 加熱炉は直径 $35 \mathrm{~mm} \phi$ のガラス管の外側にパ イロマックス線を巻いて作り，内部の様子が観察できる ようにした。温度は加熱炉内に設置した熱電対によって 測定した。

本研究では水とメタノールのそれぞれに硝酸亜鉛を溶 解したものを原料溶液とした。白金線の先端に所定の濃 度の溶液を注射器でおよそ $1 \sim 3 \mathrm{~mm} \phi$ の液滴になるよ うに付け，所定の温度になった加熱炉を素早く持ち上げ て熱天秤による重量変化測定を始めた。一方，液滴が乾 燥していく過程を, 所定の時間ごとにカメラで撮影した。

\section{2 超音波噴霧熱分解法による酸化物微粒子の合成}

硝酸亜鉛を溶媒のメ夕ノールに溶かした原料溶液を超 音波噴霧器6)で微小液滴にし, キャリアガスとともに乾 燥炉を経て熱分解炉に運んだ。本研究では主に乾燥炉の 温度と原料溶液の濃度を変えて合成を行った．熱分解反

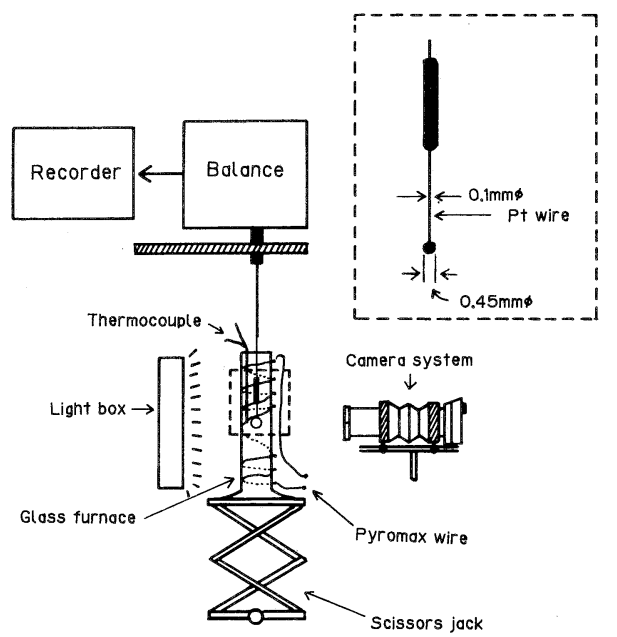

Fig. 1. Schematic diagram of single droplet drying apparatus
応によって炉内の温度が変化する恐れがあるので，熱分 解炉の温度を熱電対によって常時監視し，温度を一定に 保った。

合成した酸化亜鉛微粒子の形や粒径の測定は，粒子を イソプロピルアルコール中で超音波を用いて分散して， 走査型電子顕微鏡（SEM，日本電子 JSM-T 200）を用 いて行った。また，合成した微粒子の内部構造は粒子を ミクロトームで切断し, 同じくSEM によって観察した。

\section{3. 結果と考察}

\section{1 単一液滴の乾燥}

液滴の乾燥は基本的に 2 段階に分けることができる。 溶媒が十分に多いときは，蒸発が進行して溶質濃度が変 化しても乾燥速度が一定である。この期間は恒率乾燥期 間 ${ }^{10)}$ と呼ばれる。乾燥の後期になると, 溶媒の蒸発とと もに乾燥速度が減少するようになる。この期間は減率乾 燥期間と呼ばれる。恒率乾燥期間では蒸発により液滴の 直径が減少し, 液滴の直径の 2 乗の減少速度は液滴がほ ぼ平衡温度に達するまでの短時間を除き一定である ${ }^{11}$. すなわち，

$$
\chi \equiv-\mathrm{d}\left(X^{2}\right) / \mathrm{d} \theta
$$

ここで， $\chi$ は蒸発定数， $X$ は液滴の直径， $\theta$ は乾燥時間 である。この式を積分し， $\theta=0$ のとき $X=X_{0}$ の境界条 件を用いて，次式が得られる。

$$
X^{2}=X_{0}^{2}-\chi \theta
$$

また，最初の液滴の重量を $W_{0}$, 密度を $\rho_{\mathrm{L}}$ とすると，重 量減少量 $\Delta W$ は

$$
\begin{aligned}
& \Delta W=W_{0}-1 / 6 \pi \rho_{\mathrm{L}} X^{3} \\
& =W_{0}-1 / 6 \pi \rho_{\mathrm{L}}\left(x_{0}^{2}-\chi \theta\right)^{3 / 2} \text { より, } \\
& \left(W_{0}-\Delta W\right)^{2 / 3}=\left(\pi \rho_{\mathrm{L}} / 6\right)^{2 / 3}\left(x_{0}^{2}-\chi \theta\right)
\end{aligned}
$$

つまり, 恒率乾燥期間では $\left(W_{0}-\Delta W\right)^{2 / 3}$ は時間 $\theta$ と直 線関係にあることが分かる。一方，一般には溶媒の蒸発 速度の方が液滴内の溶質の拡散速度よりはるかに大きい ため，乾燥が進むにしたがって，液滴の表面の溶質濃度 が内部のそれよりも高くなる。表面溶質濃度が溶質の飽 和濃度より高くなったとき，表面に溶質が析出して，溶 質の殼をつくる。このような状態になると表面における 溶媒の濃度が急速に減少するので, 液滴の乾燥速度が減 少し，（3）式が成り立たなくなる．この時間を $\theta_{\mathrm{c}}$ とし， このときまでの重量減少量 $\Delta W_{\mathrm{c}}$ を測定すると（4）と (5) 式上り液滴の濃度 $C_{\mathrm{c}}$ (平均飽和濃度と呼ぶ ) と 最終粒径 $X_{\mathrm{c}}$ を見積もることができる。

$$
\begin{aligned}
& C_{\mathrm{c}}=C_{0} W_{0} /\left(W_{0}-\Delta W_{\mathrm{c}}\right) \\
& \frac{X_{\mathrm{c}}}{X_{0}}=\left\{\frac{C_{0}\left[\rho_{\mathrm{sv}}+C_{0}\left(\rho_{\mathrm{zn}}-\rho_{\mathrm{sv}}\right)\right]}{C_{\mathrm{c}}\left[\rho_{\mathrm{sv}}+C_{\mathrm{c}}\left(\rho_{\mathrm{zn}}-\rho_{\mathrm{sv}}\right)\right.}\right\}^{1 / 3}
\end{aligned}
$$

ここで， $\rho_{\mathrm{sv}}$ は溶媒の密度で， $\rho_{\mathrm{zn}}$ は溶質の硝酸亜鉛の密 度である。 $\left(W_{0}-\Delta W\right)^{2 / 3}$ と時間との関係をプロットし， 直線からはずれる点より $\theta_{\mathrm{c}}$ を見積もって粒径を求める 


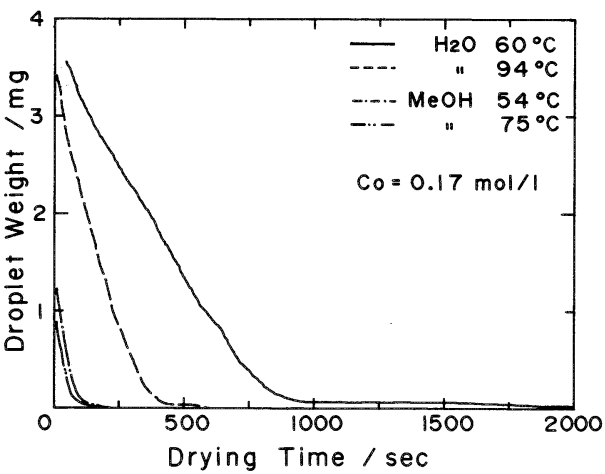

Fig. 2. Drying curves of aqueous and methanol solution of $\mathrm{Zn}\left(\mathrm{NO}_{3}\right)_{2}$ with different drying temperature.

ことを試みた。

図 2 は溶媒が水の場合上メタノールの場合の液滴の蒸 発曲線の温度依存性を示している．硝酸覀鉛の濃度はい ずれの場合も $0.17 \mathrm{~mol} / 1$ である。蒸発速度は温度が高 くなるほど大きく，また溶媒が水よりメ夕ノ一ルの方が 大きくなった。一方，乾燥の後期 $\left(\theta>\theta_{\mathrm{c}}\right)$ において曲 線の傾きが急に減少した。この傾きの変化は液滴の表面 に溶質が析出し，溶質の殼が形成されたために蒸発速度 が遅くなったためと考えられる．大部分の無機塩の溶液 の液滴の乾燥過程では溶質の殻が完成するとその後の液 滴の径は変化しなくなる. よって，このときの液滴の重 量 $\left(W_{0}-\Delta W\right)$ を蒸発曲線から見積もることができれば, 乾燥粒子の最終粒径 $\left(X_{\mathrm{c}}\right)$ を見積もることができる.

本研究では白金線による影響をできるだけ小さくする ために，0.1 mm $\phi$ 白金線を使用したが，白金線の先 端に保持できる液滴の重さはメ夕ノールの場合には 2 $\mathrm{mg}$ 以下で，水の場合には約 $4 \mathrm{mg}$ でしかない。恒率乾 燥期間の後期になると，液滴が更に小さくなるので，液 滴の蒸発に及ぼす白金線の先端の影響の増大などが考え られ，重量変化や液滴径を精度よく測定することも困難 になってくる。図 2 は実際の噴霧実験に用いている濃度 とほぼ同程度の濃度を持つ溶液を白金線につけて測定し た結果である．濃度が低い場合には生成する液滴の殼の 厚さが非常に薄くなったり，殻の生成が始まるときの液 滴径が白金球のそれとほぼ同程度になったりするので, 殻生成に対応する変曲点 $\theta_{\mathrm{c}}$ を正確に見積もることが非 常に困難になる．白金線の影響を相対的に小さく抑え， 変曲点付近の液滴の重量と半径をある程度大きくするた めに, 解析には液滴の初期濃度を図 2 の場合よりも高く して測定を行った．液滴の初期濃度を高くすることで変 曲点付近でも測定可能な液滴の重量と液滴径が保たれた が，白金球が依然として液滴内に含まれているため，実 測した液滴径は白金球の体積を含めたものになる。液滴 の初期の直径が $1.5 \mathrm{~mm}$ から $3 \mathrm{~mm}$ では, 変曲点付近の 液滴径はその初期のそれの半分以下になるが，少なくと

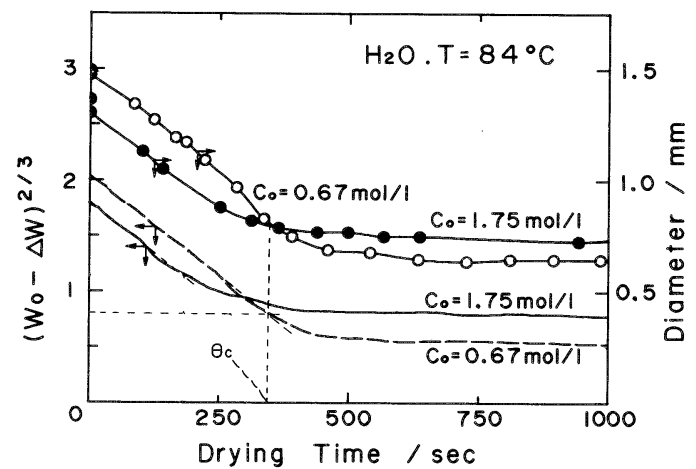

Fig. 3. $\left(W_{0}-\Delta W\right)^{2 / 3}-\theta$ curves and $X-\theta$ curves of aqueous solution of $\mathrm{Zn}\left(\mathrm{NO}_{3}\right)_{2}\left(T=84^{\circ} \mathrm{C}\right)$.

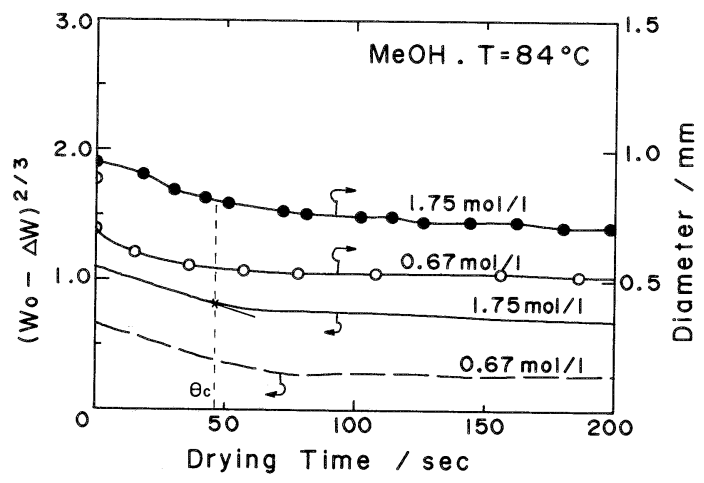

Fig. 4. $\left(W_{0}-\Delta W\right)^{2 / 3}-\theta$ curves and $X-\theta$ curves of methanol solution of $\mathrm{Zn}\left(\mathrm{NO}_{3}\right)_{2}\left(T=84^{\circ} \mathrm{C}\right)$.

も白金球の直径 $(0.4 \mathrm{~mm})$ の 2 倍程度あるので, 白金 球の存在による液滴の表面積の増加は $\theta_{\mathrm{c}}$ においておよ そ $8 \%$ で,蒸発速度に及ぼす影響は少ないと考えられる. 熱天科によって測定した $\left(W_{0}-\Delta W\right)^{2 / 3}-\theta$ 曲線から見 積もった $\theta_{\mathrm{c}}$ は溶質の殼が液滴の表面にできる時間であ るので, 重量減少曲線から $C_{\mathrm{c}}$ を見積もり， $C_{\mathrm{c}}$ を用い て計算した乾燥粒子の最終粒径に対する白金線の影響は 小さいと考えられる.

図 3 上図 4 は, 溶媒がそれぞれ水とメ夕ノールで乾燥 温度が $84^{\circ} \mathrm{C}$ のとき，初期濃度が $0.67 \mathrm{~mol} / 1$ と 1.75 $\mathrm{mol} / 1$ の液滴の蒸発曲線である。縦軸に $\left(W_{0}-\Delta W\right)^{2 / 3}$ を取ってプロットすると, 乾燥プロセスの前半の恒率乾 燥期間では $\left(W_{0}-\Delta W\right)^{2 / 3}$ と時間 $\theta$ が直線関係にある ことが分かる，この直線部分に図上で直線を引き，直線 からはずれる点を求めた。この直線からはずれる点を $\theta_{\mathrm{c}}$ とし, この点に対する $\left(W_{0}-\Delta W\right)^{2 / 3}$ の值から $\Delta W$, すなわち $\Delta W_{\mathrm{c}}$ を見積もった。

メタノールの場合には乾燥温度を $77^{\circ} \mathrm{C}, 84^{\circ} \mathrm{C}$, $106^{\circ} \mathrm{C}$ とし, 水の場合には $77^{\circ} \mathrm{C}, 84^{\circ} \mathrm{C}, 107^{\circ} \mathrm{C}, 150^{\circ} \mathrm{C}$ として各場合について，上で示した方法と同様に $\Delta W_{\mathrm{c}}$ を見積もった。このように見積もった $\Delta W_{\mathrm{c}}$ の誤差は次 
Table 1. Estimated $C_{c}$ from the drying curves of aqueous solution of $\mathrm{Zn}\left(\mathrm{NO}_{3}\right)_{2}$ at different temperatures.

\begin{tabular}{|c|c|c|c|c|}
\hline $\mathrm{T} /{ }^{\circ} \mathrm{C}$ & 77 & 84 & 107 & 150 \\
\hline \hline $\mathrm{C}_{\square} / \mathrm{mol} \cdot 1^{-1}$ & \multicolumn{5}{|c|}{0.67} \\
\hline$W_{\triangle} / \mathrm{mg}$ & 3.3 & 3.4 & 2.8 & 2.7 \\
\hline$\left(W_{\square}-W_{\mathrm{c}}\right)^{2 / 3}$ & 0.7 & 0.8 & 0.8 & 1.0 \\
\hline $\mathrm{Cc} / \mathrm{Wt} \%$ & 51 & 46 & 39 & 29 \\
\hline \hline $\mathrm{C}_{\triangle} / \mathrm{mol} \cdot 1^{-1}$ & \multicolumn{5}{|c|}{1.75} \\
\hline$W_{0} / \mathrm{mg}$ & 2.5 & 2.2 & 3.6 & 2.7 \\
\hline$\left(W_{\square}-\mathrm{Wc}^{2 / 3}\right.$ & 1.2 & 1.1 & 1.8 & 1.6 \\
\hline $\mathrm{Cc} / \mathrm{Wt} \%$ & 41 & 38 & 33 & 28 \\
\hline
\end{tabular}

Table 2. Estimated $C_{\mathrm{c}}$ from the drying curves of methanol solution of $\mathrm{Zn}\left(\mathrm{NO}_{3}\right)_{2}$ at different temperatures.

\begin{tabular}{|c|c|c|c|}
\hline $\mathrm{T} /{ }^{\circ} \mathrm{C}$ & 77 & 84 & 106 \\
\hline $\mathrm{C}_{0} / \mathrm{mol} \cdot 1^{-1}$ & \multicolumn{3}{|c|}{0.67} \\
\hline$W_{a} / \mathrm{mg}$ & 1.2 & 0.5 & 1.0 \\
\hline$\left(W_{0}-\Delta W_{C}\right)^{2 / 3}$ & 0.7 & 0.4 & 0.7 \\
\hline Cc / wt $\%$ & 29 & 28 & 22 \\
\hline $\mathrm{C}_{0} / \mathrm{mol} \cdot \mathrm{l}^{-1}$ & \multicolumn{3}{|c|}{1.75} \\
\hline$W_{\emptyset} / \mathrm{mg}$ & 1.6 & 1.2 & 0.9 \\
\hline$\left(W_{0}-\Delta W_{C}\right)^{2 / 3}$ & 1.0 & 0.8 & 0.8 \\
\hline Cc / wt\% & 40 & 38 & 32 \\
\hline
\end{tabular}

のいくつかのものによると考えられる.

(1)測定中の温度変化や熱対流による熱天科の誤差,

(2)図 3,4 で直線を引き， $\left(\theta_{\mathrm{c}}, \Delta W_{\mathrm{c}}\right)$ を決めるときに生 じる䛊差.

熱対流によって見掛け上の重量が変化するため, 熱天科 の測定値は一定とならず, 真の值の前後に変化する.こ の変化幅は温度が高いほど大きくなるが，およそ 0.1 mg である. (2)のように直線からはずれる点を図上で求 めるときに誤差が生じる. 図 3 の溶媒が水の場合には $\theta_{\mathrm{c}}$ のばらつきが $\pm 15 \mathrm{~s}$ として計算すると $\Delta W_{\mathrm{c}}$ の誤差は およそ $0.03 \mathrm{mg}$ である. 同様に図 4 の溶媒がメ夕ノ一 ルの場合には $\theta_{\mathrm{c}}$ のばらつきが $\pm 5 \mathrm{~s}$ として計算すると $\Delta W_{\mathrm{c}}$ はおよそ $0.01 \mathrm{mg}$ である.これらのことと熱天科 の精度が $0.1 \mathrm{mg}$ であることを併せて考えると $W$ の精 度は小数点以下 1 けたで, $C_{\mathrm{c}}$ の精度は $C_{0}$ より 1 けた 悪くなると考えられる.

一方, 熱天科による重量減少の測定と同時にカメラを 用いて液滴の大きさを測定し, その結果を図 3,4 に併 せてプロットした. 重量と粒径の曲線は形が類似して いるが, 図 3,4 のいずれの場合においても（ $W_{0}-$

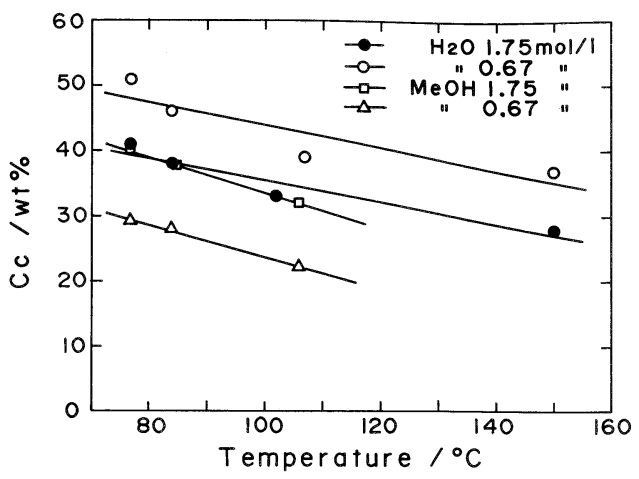

Fig. 5. Dependence of $C_{\mathrm{c}}$ on drying temperature in both cases of aqueous and methanol solutions of $\mathrm{Zn}$ $\left(\mathrm{NO}_{3}\right)_{2}$.

$\Delta W)^{2 / 3}-\theta$ 曲線から見積もった $\theta_{\mathrm{c}}$ はカメラによる粒径 がほぼ変化しなくなった時間 $\theta$ より小さかった。これ は $\left(W_{0}-\Delta W\right)^{2 / 3}-\theta$ 曲線から求めた $\theta$ は殼が生成し始 めた時刻で, 実際には殼がある厚さになるのにある程度 の時間が必要である. 粒径と重さ測定から求めた $\theta$ が 異なるのはこのようなことに起因すると思われる.ここ で上述の式を適用するには液滴の表面に溶質の殼が生成 し始めた時点での径を求める必要があるので, ( $W_{0}-$ $\Delta W)^{2 / 3}-\theta$ 曲線から見積もった $\theta_{\mathrm{c}}$ を使って $\Delta W_{\mathrm{c}}$ を見積 もり，（4）式によって液滴の平均飽和濃度を計算し,

表 1 と表 2 にまとめた。

図 5 はメタノールと水の各場合の乾燥温度と（4）式 から見積もった平均飽和濃度の関係をプロットしたもの である. いずれの場合も温度が高くなるにつれて平均飽 和濃度がほぼ直線的に低くなることが分かった。また， 平均飽和濃度の減少勾配は水よりもメタノールの方がや や大きい。これは温度が高くなるにつれてメタノールの 蒸発速度の増加率が水より大きくなるため, 飽和濃度の 減少勾配もメタノールの方がより大きくなったものと考 えられる。

見積もった $C_{\mathrm{c}}$ を用いて（5）式によって粒径を計算 することができる．この式から $C_{\mathrm{c}}$ が大きいほど $X_{\mathrm{c}}$ が 小さいことが分かる。つまり, 液滴の直径と初期濃度が 等しいならば，より高温で加熱するほど最終粒径が大き くなる.

本研究では, 乾燥過程において液滴から溶質が析出し て殼をつくり，殼が完成すると粒径が一定になると考え ている．硝酸亜鉛は $45^{\circ} \mathrm{C}$ 以上の温度で自分が持ってい る結晶水に溶けるので, 測定温度範囲では溶質の款がこ のような硝酸亜鉛の融液からできている. 図 6 は図 4 中 の $\theta=0, \theta=72 \mathrm{~s}, \theta=420 \mathrm{~s}$ で撮影した液滴の写真であ る. $\theta=72 \mathrm{~s}$ から液滴径が変わらなくなったが，この点 に対応する液滴の写真（図6(b)）では液滴の表面に硝 酸亜鉛の融液ができたため，固相殻はみられない。更に 


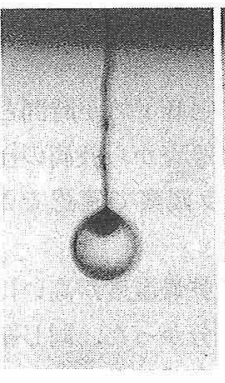

(a)

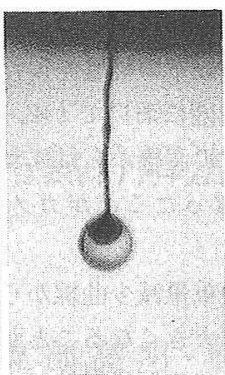

(b)

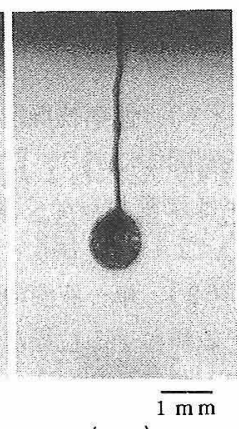

(c)
Fig. 6. Photographs of the droplet dried at $84^{\circ} \mathrm{C}$. ( $C_{0}=1.75 \mathrm{~mol} / 1$, solvent : $\mathrm{CH}_{3} \mathrm{OH}$ )

(a) $\theta=0$, (b) $\theta=72 \mathrm{~s}$, (c) $\theta=420 \mathrm{~s}$

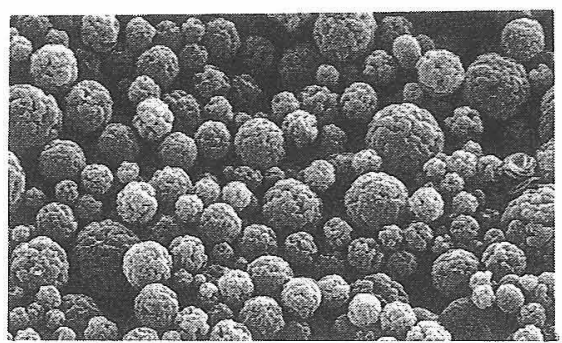

(a)

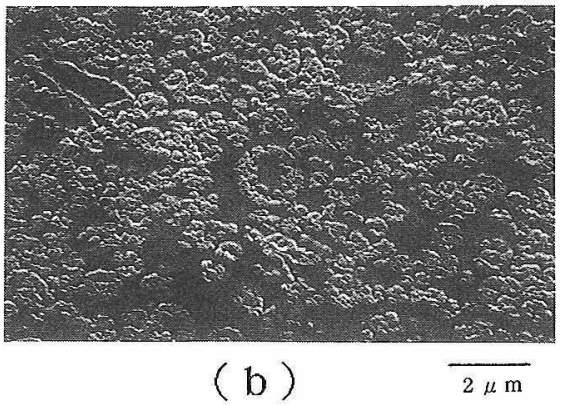

Fig. 7. SEM photographs of $\mathrm{ZnO}$ particles derived from methanol solution of $\mathrm{Zn}\left(\mathrm{NO}_{3}\right)_{2} . \quad\left(C_{0}=0.10 \mathrm{~mol} / 1\right.$, $T_{\mathrm{a}}=200^{\circ} \mathrm{C}$ )

(a) $\mathrm{ZnO}$ particles, (b) Microtomed

時間を加けて乾燥すると図 6(c) $(\theta=420 \mathrm{~s})$ のように 結晶水が徐々に蒸発し, 硝酸垔鉛の固相が晶出した。 $\theta_{\mathrm{c}}$ で液滴の表面に融液の膜ができると内部にある溶媒がこ の膜を通って表面に拡散していくが，拡散が遅く溶媒に よる内部蒸気圧が高くなった場合，液滴が膨張するこ上 がある.しかし，本研究では図 $3 ， 4$ で分かるように内 部蒸気圧の圧力による液滴の膨張はみられなかった。し たがって, 実際の噴霧熱分解に用いる液滴の乾燥も上述 のように進行し，粒径が乾燥温度しともに大きくなると 考えられる。

\section{2 噴露熱分解法による酸化亜鉛微粒子の合成}

図 7 は原料濃度が $0.10 \mathrm{~mol} / 1$ ，乾燥温度が $200^{\circ} \mathrm{C}$, 熱 分解温度が $550^{\circ} \mathrm{C}$ の条件下で合成した酸化亜鈆の外形

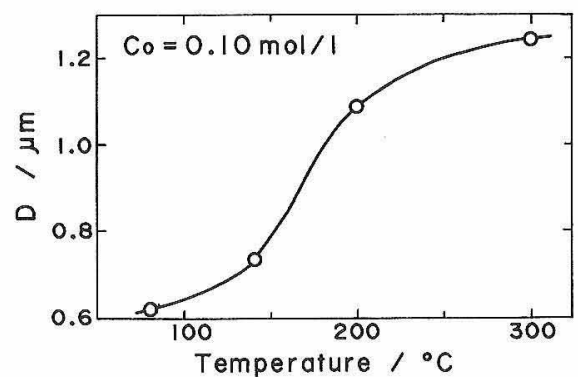

Fig. 8. Dependence of $\mathrm{ZnO}$ particle size on drying temperature. $\left(\mathrm{C}_{0}=0.10 \mathrm{~mol} / \mathrm{l}\right.$, solvent : $\left.\mathrm{CH}_{3} \mathrm{OH}\right)$

(a) とミクロトームで切断した微粒子の内部 (b) の SEM 写真である。合成した微粒子は球状で，粒度分布 が狭く分散性がよいことが分かる.また，噴霧熱分解過 程で溶媒の激しい蒸発による液滴の分裂はみられなかっ た. 写真（b）では球が中空で，固相殼の存在がはっき り分かる。これは乾燥段階で形成した硝酸亜鉛の融液壳 が熱分解炬で酸化亜鉿に分解して残ったものである。

図 8 は熱分解温度を $550^{\circ} \mathrm{C}$ に, 原料溶液の濃度を 0.1 $\mathrm{mol} / 1$ と一定にし, 乾燥温度を $80^{\circ} \mathrm{C}$ から $300^{\circ} \mathrm{C}$ まで変 化させて合成した微粒子の粒径変化を示したものであ る。粒径が温度とともに増大し，その関係はS 字型で $140^{\circ} \mathrm{C}$ から $200^{\circ} \mathrm{C}$ の間で急に増加した。この結果を図 5 と比較すると単一液滴の乾燥に関する実験は $77^{\circ} \mathrm{C}$ か ら $150^{\circ} \mathrm{C}$ までの範囲しか行っていないので, 図 5 は図

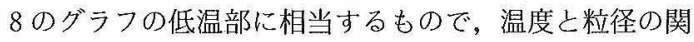
係はよく対応している。このことは二つの場合とも粒径 の温度依存性は基本的に同じ機構によると考えられる。 したがって，すでに図 5 で説明した温度と粒径の関係は 図 8 でも認められ，単一液滴の乾燥実験で得た温度と粒 径の結果は噴霧熱分解法の場合と同じ傾向を示したと考 えてよい.

噴霧熱分解法の合成実験で用いた硝酸垔鉛の濃度はお よそ $0.1 \mathrm{~mol} / 1$ で, 単一液滴の乾燥実験に用いた濃度の 十分の一程度である。図 5 で分かるように初期濃度が異 なっても $C_{c}$ の温度依存性の傾向が同じであった。これ は初期濃度が異なっても蒸発が同じ速度式にしたがって 進行するためと考えられる。

次に，乾燥温度と熱分解温度をそれぞれ $200^{\circ} \mathrm{C}$, $550^{\circ} \mathrm{C}$ にして原料溶液の濃度を変えて酸化亜鉛微粒子を 合成した。図 9 に横軸に濃度の対数，縦軸に平均粒径の 対数をプロットした，得られた直線の傾きが $1 / 3$ であっ た。すなわち粒径 $(d)$ の 3 乗が原料濃度 $\left(C_{0}\right)$ に比例 して变化する。

$$
d^{3}=k_{1} C_{0}
$$

1 個の液滴から 1 個の粒子ができ，原料濃度による液滴 径の変化を無視できるなら，粒子の重さ $(W)$ が原料 濃度 $\left(C_{0}\right)$ に比例する。 


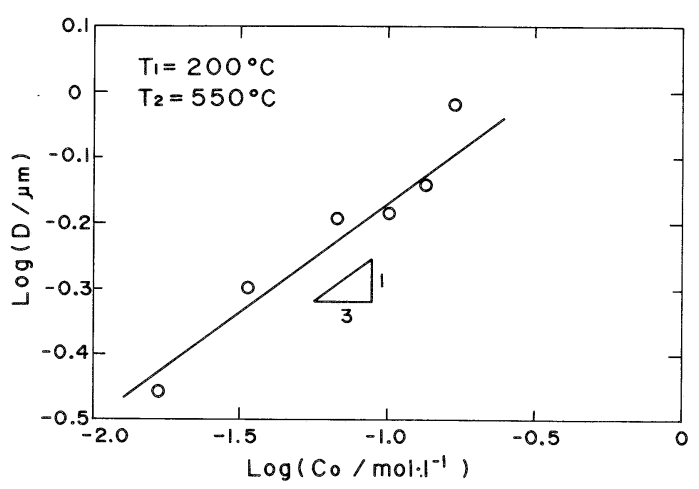

Fig. 9. Dependence of $\mathrm{ZnO}$ particle size on concentration of starting solutions. $\left(\mathrm{T}=200^{\circ} \mathrm{C}\right.$, solvent : $\left.\mathrm{CH}_{3} \mathrm{OH}\right)$

$$
W=k_{2} C_{0}
$$

このことと, 粒子の体積 $(V)$ は $V=(1 / 6) \pi d^{3}=k_{3} d^{3}$ の関係から，原料濃度が変わっても得られる粒子の見掛 け密度 $(W / V)$ は

$$
\begin{aligned}
W / V & =\left(k_{2} d^{3} / k_{1}\right) /\left(k_{3} d^{3}\right) \\
& =k_{2} /\left(k_{1} k_{3}\right) \\
& =\text { const. }
\end{aligned}
$$

となることが分かる．言い換えれば乾燥温度が一定であ れば生成した粒子の気孔率は原料濃度に依存せず，一定 である。

\section{4. 結 論}

本研究では, 単一液滴の蒸発, 乾燥挙動を熱天科と力 メラを使って研究し, 乾燥段階が液滴に及ぼす影響につ
いて調へ，更に実際の噴霧熱分解法の結果と対比させて 検討した。 そして，以下の結論を得た。

（1）恒率乾燥段階において $\left(W_{0}-\Delta W\right)^{2 / 3}$ が時間と 直線関係にあり，この直線からはずれる点から液滴の径 がほぼ変わらなくなったことがカメラ観察で確認でき た。

（2）単一液滴の重量減少曲線から乾燥温度が高いほ ビ乾燥粒子の粒径が大きくなることが分かった。同じ結 果が噴霧熱分解法で酸化亜鉛微粒子を合成したときにも 得られた。

（３）乾燥温度が一定であれば，粒径は濃度の $1 / 3$ 乗 に比例して変化する。

\section{文献}

1）徳永文博, 陶山容子, 加藤昭夫, 粉体および粉末治金, 24, 43-47 (1977).

2）加藤昭夫, 徳永文博, ibid., 24, 219-22 (1977).

3）神崎修三，平尾喜代司，大津賀 望，斉藤勝一，中川善 兵衛, 浜野健也, 窯協, 91, 81-86 (1983).

4) T. J. Gardner and G. L. Messing, Am. Ceram. Soc, Bull., 63, 1498-504 (1984).

5）石沢 均, 桜井 修, 水谷惟恭, 加藤誠軌, 窯協, 93, 382-86 (1985).

6) H. Ishizawa, O. Sakurai, N. Mizutani and M. Kato, Am. Ceram. Soc. Bull., 65, 1399-404 (1986).

7) 亀井三郎, 監見四郎, 工業化学雑誌, 40, 865-76 (1937).

8) W.E. Ranz and W.R. Marshall, Jr., Chem. Eng. Prog., 48, 141-46 (1952).

9) D. H. Charlesworth and W. R. Marshall, Jr., A. I. Ch. E. J. 6, 9-23 (1960).

10）川北公夫, 小石真純, 種谷真一, “粉体工学 (応用編)”, 橫書店 (1974) p. 35 .

11）甲藤好郎, “伝熱概論”, 養賢堂 (1964) pp. 231-41. 